\title{
PRINCIPLES OF PHARMACOTHERAPY \\ OF CARDIOVASCULAR DISEASES WITH HELP \\ OF MEDICINAL PRODUCTS BASED ON MEDICINAL PLANTS
}

\section{Sakhanda Ivanna ${ }^{1}$ \\ Kosyachenko Kostyantyn ${ }^{2}$}

DOI: http://dx.doi.org/10.30525/978-9934-571-31-2_9

Abstract. In recent years, a fundamentally new approach to the treatment of cardiopathology is actively developing, so it consists of the combined use of traditional drugs and medicinal products of plant origin (MP PO), because herbal remedies are mostly compatible with each other and with synthetic medicines, which leads to synergy of their action. Methodology. Situational analysis of the target segment of finished medicinal products (MP) of plant origin for 2012-2017 was held and it indicates a significant potential for using them as a drug therapy or as a preventive measure in many diseases. The purpose of this work is to briefly consider, on specific examples, the main methods of treating cardiovascular diseases with medicinal plants. Some plants, used to treat cardiovascular diseases, have been considered. The list of plants, that were given, reflects the main approaches to phytotherapy of diseases of the cardiovascular system: this is the use of cardiac glycosides - the first highly effective drugs for the treatment of heart failure, P-active compounds, strengthen the blood vessels and regulate metabolism in the body, a variety of alkaloids, including stimulating the activity of the body, which is important, for example, in hypotension. A number of medicinal plants are representatives of the ruderal flora (motherwort). It causes widespread use of plants in folk medicine. Individual plants are introduced into the culture to produce medicinal products based on them (Valerian, Digitalis, Periwinkle, Astragalus).

\footnotetext{
${ }^{1}$ Master of Pharmacy,

Assistant at Department of Pharmacy and Industrial Drug Technology,

Bogomolets National Medical University, Ukraine

${ }^{2}$ Doctor of Pharmacy, Professor,

Head at Department of Organization and Economy of Pharmacy,

Bogomolets National Medical University, Ukraine
} 


\section{Principles of pharmacotherapy of cardiovascular diseases with help of...}

\section{Introduction}

In developed countries, mortality from cardiovascular disease is one of the highest. This is due to a heavy load on the nervous system, which soon leads to hypertension, a sedentary lifestyle of a significant part of the population, because of which the body does not receive the necessary nutritional support for normal functioning of all the physical load systems, which leads to the deposition of atherosclerotic plaques in the vessels. The effect of these factors on the person - heart attacks and strokes.

For the treatment of cardiovascular diseases, various drugs are being developed and used. Their high therapeutic effect is due to a powerful specific effect on a certain process in the body.

Plants with healing properties are the first medicines that a person began to use. Many of the currently common pharmaceutical preparations are isolated from medicinal plants or created with their use. The peculiarity of many medicinal plants is a nonspecific effect on the body, side effects in a number of medicinal plants are not so pronounced.

Medicinal plants are an effective means of preventing many cardiovascular diseases in risk groups. They are also often used as an auxiliary therapy. The centuries-old experience of using medicinal plants in folk medicine is the result of both their rather high efficiency and their wide distribution in natural ecosystems, and sometimes near human habitation. A number of medicinal plants are grown on plantations as raw materials for the pharmaceutical industry.

The purpose of this work is to briefly consider, on specific examples, the main methods of treating cardiovascular diseases with medicinal plants.

Substances that normalize blood circulation are often used in practical medicine in violation of heart activity and pathological changes in vascular tone. Based on the clinical application of these drugs, the following groups can be distinguished.

I. Remedies for heart disorders:

a) with heart failure;

b) for violations of the rhythm of heartbeats;

c) with insufficient blood supply to the myocardium.

II. Remedies used in pathological conditions accompanied by changes in blood pressure:

a) with arterial hypertension;

b) with hypotensive states. 
For more than 200 years, cardiac glycosides have been the main drugs for the treatment of patients with heart decompensation. However, a more detailed study of the genesis of chronic heart failure and a broad comparative study of cardiac glycosides and other cardiotonics regarding their efficacy and safety over the past two-three decades has led to a revision of their significance in the treatment of chronic heart failure. It turned out that cardiotonics for some time improve the quality of life of patients, but life expectancy not only does not extend, but when using many "non-glycoside" drugs can even be shortened (partly as a result of their arrhythmogenic effect). Although cardiotonics are still being used, they are only one of the components in the complex treatment of chronic heart failure.

The main principle of pharmacotherapy of this pathology is to create the most optimal conditions for the work of the heart. It is advisable to increase the effectiveness of its work not so much through direct cardiostimulating action, as by reducing the excessive burden on the contractile myocardium and creating the most sparing mode of its operation. In a broad sense, this refers to the cardioprotective action of drugs. This can be achieved by improving the blood supply and metabolism of the myocardium, reducing preload and afterload on the heart, normalizing the rhythm of heartbeats, reducing the volume of circulating blood, normalizing the function of the blood coagulation system, etc.

Rational pharmacotherapy of chronic heart failure includes a large complex of medicines of different directionality of action. Next we will consider cardiotonic agents (cardiac glycosides).

Cardiac glycosides are substances of plant origin that have a pronounced cardiotonic effect. They increase the efficiency of the myocardium, providing the most economical and, at the same time, effective heart activity. Cardiac glycosides are used in the treatment of heart failure, which most often develops against the background of coronary heart disease, myocardial lesions of different etiology and heart rhythm disturbances.

In medical practice, cardiac glycosides preparations are used, so they are obtained from the following plants [7, p. 12-14]:

Digitalis purple (Digitalis purpurea) - digitoxin;

Woolly foxglove (Digitalis lanata) - digoxin, ceelanid (lanatoside C, isolanide);

Strophete Kombyo (Strophanthus Kombé) - strofantin K; 
Lily of the valley (Convallaria) - korglikon;

Adonis (Adonis vernalis) - infusion of herbs of Adonis.

Sources for the production of cardiac glycosides, the drugs used and their active principles are given in Table 1. The most interesting are individual glycosides. The main property of cardiac glycosides is their selective effect on the heart. Strengthening of the systole (cardiotonic action, positive inotropic action), associated with the direct effect of drugs on the myocardium, plays a major role in the pharmacotherapeutic effect of cardiac glycosides.

Table 1

Plants and preparations containing cardiac glycosides

\begin{tabular}{|c|c|c|c|c|}
\hline \multirow[b]{2}{*}{ Plant } & \multirow{2}{*}{$\begin{array}{l}\text { Parts of } \\
\text { the plant, } \\
\text { used for the } \\
\text { manufacture } \\
\text { of drugs }\end{array}$} & \multicolumn{2}{|c|}{ Preparations } & \multirow{2}{*}{\begin{tabular}{|c|} 
Cardiac \\
glycosides \\
contained in \\
new-galenic \\
preparations \\
and preparations \\
of individual \\
glycosides \\
\end{tabular}} \\
\hline & & $\begin{array}{c}\text { Simple, } \\
\text { galenic } \\
\text { and } \\
\text { infusions }\end{array}$ & $\begin{array}{l}\text { New-galenic } \\
\text { and individual } \\
\text { glycosides }\end{array}$ & \\
\hline $\begin{array}{l}\text { Digitalis } \\
\text { (Digitalis) purple } \\
\text { (purpurea) } \\
\text { rusty (ferruginea) } \\
\text { woolly (lanata) }\end{array}$ & Leaves & $\begin{array}{l}\text { Powder } \\
\text { Extract }\end{array}$ & \begin{tabular}{|l} 
Digitoxin \\
Gitoxin \\
Cordigit \\
Digalen-neo \\
Lantozide \\
Digoxin \\
Celanide
\end{tabular} & \begin{tabular}{|l} 
Digitoxin \\
Gitoxin \\
Digitoxin and \\
Gitoxin \\
Digitoxin, Gitoxin \\
\\
Digoxin \\
Lantozide-C \\
(Dihylanide-C) \\
\end{tabular} \\
\hline $\begin{array}{l}\text { Smooth strophant } \\
\text { (Strophanthus } \\
\text { gratus) } \\
\text { Strophant } \\
\text { Kombyo } \\
\text { (Strophantus } \\
\text { Kombe) } \\
\end{array}$ & Seeds & & $\begin{array}{l}\begin{array}{l}\text { Strophanthine G } \\
\text { (ouabain) }\end{array} \\
\text { Strophanthine K }\end{array}$ & $\begin{array}{l}\text { Strophanthine-G } \\
\text { K- Strophanthine } \\
\text { K- Strobathoside }\end{array}$ \\
\hline $\begin{array}{l}\text { Lily of the valley } \\
\text { (Convallaria) }\end{array}$ & \begin{tabular}{|l} 
Grass \\
(leaves and \\
inflorescences)
\end{tabular} & Tincture & Korglikon & $\begin{array}{l}\text { Covallasid } \\
\text { Convallatoxin }\end{array}$ \\
\hline $\begin{array}{l}\text { Adonis (Adonis } \\
\text { vernalis) }\end{array}$ & Grass & \begin{tabular}{|l|} 
Infusion \\
Extract
\end{tabular} & Adonisid & $\begin{array}{l}\text { Adonitoxin } \\
\text { Tsimarin }\end{array}$ \\
\hline $\begin{array}{l}\text { Onions Marine } \\
\text { (Scilla maritima) }\end{array}$ & Bulbs & Tincture & Szilaren & Szilaren \\
\hline
\end{tabular}


Cardiac glycosides markedly increase the stroke and minute volume of the heart with heart failure. It is important that the work of the heart is increased without increasing oxygen consumption (per unit of work).

It is important that the work of the heart rises against the background of a decrease in the heart rate (negative chronotropic action) and diastole lengthening. It creates the most economical mode of the heart: strong systolic contractions are replaced by sufficient periods of "rest" (diastole), favorable for the restoration of energy resources in the myocardium. The decrease in the rhythm of the heartbeats is largely due to the cardio-cardiac reflex. Under the influence of cardiac glycosides, the endings of the sensitive nerves of the heart are excited and, reflexively, a bradycardia arises through the system of vagus nerves. It is not excluded that a certain role is played by the intensification of heart reflexes from the mechanoreceptors of the sinoaortic zone during systole as a result of an increase in blood pressure. In addition, cardiac glycosides, having a direct inhibitory effect on the conduction system of the heart and toning the vagus nerve, reduce the rate of excitation (negative dromotropic action).

With heart failure, an increase under the influence of cardiac glycosides of its minute volume has a positive effect on blood circulation as a whole (Table 2).

The main effect of cardiac glycosides on blood circulation in decompensating the heart is to reduce venous stasis. At the same time, venous pressure decreases and edema gradually disappears. The reflex increase in the heart rate (Bainbridge reflex from the mouth of the upper hollow veins) does not occur with the elimination of venous stasis. The arterial pressure does not change or rises (if it was lowered). Total peripheral resistance of blood vessels decreases, blood supply and oxygenation of tissues improve. Disrupted functions of internal organs (liver, gastrointestinal tract, etc.) are restored. due to the normalization of the general hemodynamics, cardiac glycosides can improve the blood supply of the heart (a slight direct coronary-exerting effect is noted in the preparations of digitalis, when these drugs are administered at high doses).

Until now, it was a question of the general properties of cardiac glycosides. However, different drugs have certain differences. It concerns the activity, the rate of development of the effect, its duration, as well as the pharmacokinetics of the substances. 
Effects of cardiac glycosides in heart failure

\begin{tabular}{|c|c|c|}
\hline Parameters, function & $\begin{array}{l}\text { Changes in the } \\
\text { cardiovascular system } \\
\text { with heart failure }\end{array}$ & $\begin{array}{l}\text { Effects of cardiac glycosides } \\
\text { in heart failure }\end{array}$ \\
\hline \multicolumn{3}{|c|}{ Changes in the activity of the heart } \\
\hline $\begin{array}{l}\text { Systole } \\
\text { Diastole } \\
\text { Shock volume } \\
\text { Minute volume (cardiac } \\
\text { output) } \\
\text { Heart rate } \\
\text { Carrying out pulses } \\
\text { through the cardiac } \\
\text { conduction system }\end{array}$ & $\begin{array}{l}\text { Weakened } \\
\text { Shortened } \\
\text { Increased }\end{array}$ & $\begin{array}{l}\text { Strengthens and shortens } \\
\text { Extends } \\
\text { Approach the norm (decrease) } \\
\text { Increases } \\
\text { Decreased } \\
\text { Slows down }\end{array}$ \\
\hline \multicolumn{3}{|c|}{ Changes in blood circulation } \\
\hline $\begin{array}{l}\text { Venous pressure } \\
\text { Arterial pressure } \\
\text { Blood supply to the heart } \\
\text { Volume of circulating } \\
\text { blood }\end{array}$ & $\begin{array}{l}\text { Increased } \\
\text { Sometimes reduced } \\
\text { Insufficient } \\
\text { Increased }\end{array}$ & $\begin{array}{l}\text { Approaching the norm } \\
\text { (decreasing) } \\
\text { Approaching the norm (rising) } \\
\text { Approaching the norm } \\
\text { (improves) } \\
\text { Approaching the norm } \\
\text { (decreasing) }\end{array}$ \\
\hline \multicolumn{3}{|c|}{$\begin{array}{l}\text { Changes in the functions of organs and tissues, } \\
\text { associated with the state of the circulation }\end{array}$} \\
\hline $\begin{array}{l}\text { Extracellular fluid in } \\
\text { tissues } \\
\text { Diuresis } \\
\text { Functions of a number } \\
\text { of other internal organs } \\
\text { (liver, digestive tract, etc.) }\end{array}$ & $\begin{array}{l}\text { Edema } \\
\text { Reduced (oliguria) } \\
\text { Disrupted (due to } \\
\text { venous congestion) }\end{array}$ & $\begin{array}{l}\text { Disappearance of edema } \\
\text { Approaching the norm (rising) } \\
\text { Approaching the norm }\end{array}$ \\
\hline
\end{tabular}

By activity, cardiac glycosides differ quite significantly. biological standardization is used in determining the activity of medicinal raw materials and many drugs (galenic, new-galenic, etc.). In this case, the activity of cardiac glycosides is most often indicated by frogy units of action (ICE).

The required activity of the medicinal raw material, containing a number of cardiac glycosides, and the activity of individual glycosides are given for example. 


Medicinal raw materials
$1 \mathrm{~g}$ of Digitalis leaves contains 50-66 ICE
$1 \mathrm{~g}$ of Adonis herb contains 50-66 ICE
$1 \mathrm{~g}$ of Lily-of-the-valley grass contains $120 \mathrm{ICE}$
$1 \mathrm{~g}$ of Strophant seed contains 2000 ICE
$\underline{\text { Individual glycosides }}$
$1 \mathrm{~g}$ Digitoxin contains $8000-10000 \mathrm{ICE}$
$1 \mathrm{~g}$ of Celanide contains $14000-16000 \mathrm{ICE}$
$1 \mathrm{~g}$ of Konvallyatoxin contains $63000-80000 \mathrm{ICE}$
$1 \mathrm{~g}$ of Strophanthin K contains 44000-56000 ICE.
Thus, the biological activity of strophanthin K and konvallyatoxin (lily
of the valley glycoside) is significantly higher than that of digitalis digitoxin
and celoid glycosides.

In the clinic, the activity of cardiac glycosides can be judged by equi-effective doses when they are administered intravenously.

Differences in cardiac glycosides are also included in the duration of the latent period of action and the rate of increase in the effect. Thus, with intravenous administration, strophanthin and konvalyatoksin begin to act on the heart after 5-10 min, and ceulanid - after 5-30 min.

When using substances in equally effective doses and the same route of administration (intravenous), the maximum effect is particularly rapid in strophanthin and konvallyatoxin (after 30 min-1.5 h), then - Celanide and digoxin (1-5 h), and digitoxin (4-12 h). Consequently, even among the medicines of digitalis, the rate of development of the effect is not the same. By the rate of cardiotropic effect development, cardiac glycosides can be represented by the following series: strophantine $>$ konvallyatoxin $>$ celanide $>$ digoxin $>$ digitoxin.

The duration of the cardiotonic influence of cardiac glycosides is determined by the rate of their inactivation in the body, by binding to plasma proteins and the rate of excretion (see Table 3). Preparations of Strophanthus, Adonis and Lily of the valley are usually excreted within a day or several more. Glycoside Digitalis purple digitoxin causes a particularly prolonged effect (elimination lasts 2-3 weeks). Glycosides of Digitalis woolly digoxin and celanide occupy an intermediate position (the time of their elimination 3-6 days).

An important characteristic of cardiac glycosides is their ability to accumulate. The longer the cardiac glycosides act, the more they cumulate. We are talking about material cumulation (the accumulation of the substance 
Comparative characteristics of a number of cardiac glycosides of digitalis and stropathy

\begin{tabular}{|c|c|c|c|c|c|c|c|c|c|}
\hline \multirow[b]{2}{*}{ Preparation } & \multirow{2}{*}{ 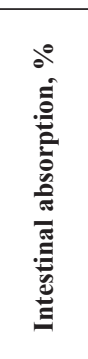 } & \multicolumn{2}{|c|}{ Latent period } & \multicolumn{2}{|c|}{$\begin{array}{c}\text { Speed of } \\
\text { maximum effect } \\
\text { development }\end{array}$} & \multicolumn{3}{|c|}{$\begin{array}{l}\text { Rate of excretion } \\
\text { of the substance }\end{array}$} & \multirow[b]{2}{*}{ } \\
\hline & & 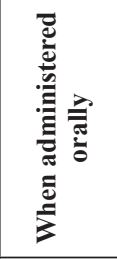 & 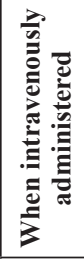 & 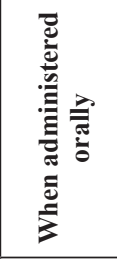 & 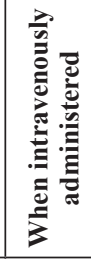 & 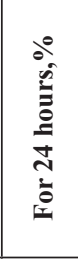 & 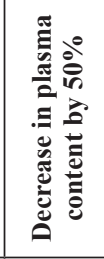 & 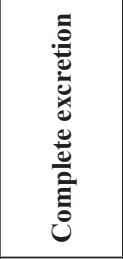 & \\
\hline Digitoxin & 90-100 & $2 \mathrm{~h}$ & \begin{tabular}{|l|}
$30-90$ \\
$\mathrm{~min}$
\end{tabular} & $12 \mathrm{~h}$ & $4-12 \mathrm{~h}$ & $7-10$ & 8-9 days & \begin{tabular}{|l|}
$2-3$ weeks \\
or more
\end{tabular} & $+1+1+$ \\
\hline Digoxin & $50-80$ & $\begin{array}{l}30 \mathrm{~min}- \\
2 \mathrm{~h} \\
\end{array}$ & \begin{tabular}{|l|}
$5-30$ \\
$\mathrm{~min}$
\end{tabular} & $6-8 \mathrm{~h}$ & $1-5 \mathrm{~h}$ & $20-30$ & $34-36 \mathrm{~h}$ & 2-7 days & +++ \\
\hline Strophantine & $2-5$ & $\begin{array}{l}\text { Not } \\
\text { applicable }\end{array}$ & $\begin{array}{l}5-10 \\
\min \end{array}$ & $\begin{array}{l}\text { Not } \\
\text { applicable }\end{array}$ & \begin{tabular}{|l|}
$30-90$ \\
$\mathrm{~min}$
\end{tabular} & $85-90$ & $8 \mathrm{~h}$ & 1-3 days & ++ \\
\hline
\end{tabular}

itself in the body). A particularly pronounced cumulation was noted for digitoxin. This is due to slow processes of inactivation and excretion of digitoxin from the body $\left(\mathrm{t}_{1 / 2} \approx 160 \mathrm{~h}\right)$. digoxin $\left(\mathrm{t}_{1 / 2} \approx 34-36 \mathrm{~h}\right)$ and celanid cumulates less.

Approximately $7 / 8$ of the administered dose of strophanthin is excreted in the first 24 hours, so when it is used, cumulation is expressed to a small extent. By the duration of the action and the ability to accumulate glycosides, digitalis and strophanthin are arranged in the following order: Digitoxin $>$ Digoxin $>$ Celanide $>$ Strophanthin. Preparations of Adonis and lily of the valley cumulate even less than strophanthin.

Preparations of cardiac glycosides are absorbed from the gastrointestinal tract unequally. More lipophilic digitoxin (90-95\%) and digoxin (50-80\%) are absorbed very well, - celanide (20-40\%) is absorbed well. Strophanthin is very poorly absorbed (2-5\%) and partially destroyed. Glycosides of the lily of the valley are largely destroyed in the digestive tract. Therefore enterally expediently to enter mainly preparations of digitalis (digoxin). Inside take also drugs of Adonis (infusion of herbs of Adonis).

Cardiac glycosides are distributed to different organs and tissues after absorption. In the heart, no more than $1 \%$ of the administered dose is detected. Thus, the main directionality of the action of cardiac gly- 
cosides is explained by the high sensitivity of the heart tissues to this group of drugs.

Part of the introduced glycosides reversibly binds to plasma albumins (eg, digoxin by $30-35 \%$, strophanthin by less than $5 \%$ ).

Cardiac glycosides and the products of their transformation are mainly excreted by the kidneys, and also with bile (they are partially absorbed from the intestine). The duration of action of cardiac glycosides increases with renal pathology.

Digitoxin is excreted mainly in the form of metabolites and conjugates. Digoxin is only in a small part subjected to chemical transformations. Strophanthin is excreted unchanged.

Cardiac glycosides are mainly used for acute and chronic heart failure. In acute heart failure, cardiac glycosides with a short latent period (strophanthin, korglikon) are administered. Digoxin is the main drug for oral administration for chronic heart failure. Sometimes glycosides (mostly foxglove preparations) are prescribed for cardiac arrhythmias (with atrial fibrillation, with paroxysmal atrial and nodular tachycardia).

Cardiac glycosides are injected more often inside (preparations of foxglove, Adonis) and intravenously (strophanthin, digoxin, tselanid, korglikon), sometimes - intramuscularly and rectally. Subcutaneous injections are inexpedient, because they can cause unwanted reactions - irritation at the injection site, pain, abscesses.

Incomplete atrioventricular block, pronounced bradycardia, acute infectious myocarditis are contraindications to the use of cardiac glycosides. Gently use cardiac glycosides with calcium preparations and with hypokalemia. This is due to the fact that with an increased content of calcium ions in the blood serum, the sensitivity of the myocardium to cardiac glycosides increases and, accordingly, the possibility of toxic effects of these drugs increases. Similarly, the effect of cardiac glycosides varies with a decrease in the potassium ion content (which can occur with the use of diuretics, diarrhea, postoperative diuretics).

\section{Effective methods of treatment and prevention of cardiovascular diseases with phytotherapy}

Diseases of the cardiovascular system firmly occupy a leading position in the list of diseases that affect the population, regardless of the age and physiological characteristics of its representatives. Various kinds of disorders of 
the cardiovascular system are the main cause of development of dangerous diseases, worsening of general health, risk of severe pathology. To prevent the emergence of serious ailments, the general strengthening of the circulatory system, traditional medicine offers the use of medicinal and prophylactic purposes of plants whose medicinal properties are checked by time [2, p. 12-13].

Violations of the cardiovascular system and the appearance of characteristic diseases are caused by such factors as slagging of the body due to malnutrition, the formation of cholesterol plaques in the cavity of the vessels, decrease in their density and elasticity.

To eliminate the negative phenomena, it is recommended to use various herbs that will help cure existing diseases or prevent the occurrence of such diseases [3, p. 156].

The composition of most medicinal plants is enriched with a large number of antioxidant substances, flavonoids, essential oils, vitamin complexes and other important microelements.

Regular consumption of decoctions and infusions, prepared on the basis of medicinal herbs as a medicinal product, makes it possible to obtain the following positive results:

1. Systematically occurring stress, nervous overstrain, depressive conditions often become the causes of vascular disease. Any phytotea for vessels and myocardium, the composition of which is enriched with valerian or melissa, will help to have a soothing effect and bring the psychoemotional state of the patient into relative norm.

2. The beneficial effect of medicinal fees promotes stimulation of circulatory processes, which in turn increases the number of incoming nutrients and oxygen to organs and tissues at times.

3. Some types of plants help significantly reduce pressure and bring the patient into a relatively normal state.

4. But it should be remembered that permanent effect with the help of such remedies can only be provided by long-term use.

5.Penetrating into the tissues of vessels and veins, the active components contribute to their strengthening, increasing elasticity and preventing the fragility of the vascular walls.

The spectrum of medicinal plants, used in the treatment of vascular pathologies and diseases, is incredibly extensive. To achieve the desired result, you should choose a certain plant that has properties which help to eliminate existing pathologies. 


\section{One-component charges}

A variety of medicinal herbs for the cardiovascular system are used primarily for the preparation of multicomponent collections, which include several species of plants that have properties that promote the strengthening and improvement of the circulatory system.

However, in order to prevent characteristic diseases, stimulate blood flow, provide soothing and relaxing action, it is better to take single-component herbal teas, the range of recipes for cooking is more than wide, which is confirmed by the instruction given below.

Valerian

Valerian belongs to the number of plants that are most often used in the treatment of vascular and cardiac muscle diseases in folk and traditional medicine. In order to obtain the desired result, it is necessary to take the remedies, prepared with this herb, for two - three months.

Herbal teas for the myocardium and vessels, which include valerian, subject to their regular use, contribute to the removal of spasms, vasodilation, stimulation of the circulatory processes.

For the prevention and treatment of diseases, you can use the following recipe:

- a teaspoon of pre-ground roots pour a glass of boiling water;

- further the infusion should be held on low heat for a minimum of five minutes;

- the product should be cooled and filtered.

Take this infusion should be small portions - not more than 1 tablespoon. It is recommended to do this three times a day, immediately after the main meals.

\section{Motherwort}

To improve the activity of the circulatory system, the tincture of the motherwort, prepared in industrial conditions, is mainly used. But for the prevention of diseases and pathologies, you can use and infusion, prepared at home.

To do this, pour 1 teaspoon of pre-crushed raw materials and a half cups of boiling water, then give the agent a little brew. Use it three times during the day, doing each time for a small gulp.

\section{$\underline{\text { Peppermint }}$}

Effective strengthening of the heart and blood vessels with herbs can be done through a therapeutic course, including the use of medicinal tea, pre- 
pared on the basis of peppermint. Take a ready-made broth in the morning, immediately after awakening. After consuming a drink, you should stop taking food for at least half an hour.

To prepare the product, you should brew 1 teaspoon dried and ground mint leaves with a glass of steep boiling water, then wrap the container with drinks and leave it for about an hour. It is permissible to prepare therapeutic tea from the evening.

Multicomponent herbal collections, which include various types of plants, are among the most effective remedies to help cope with diseases of the cardiovascular system [6, p. 96].

You can buy any collection of herbs in a pharmacy, the price of such funds is more than democratic. But independent preparation of raw materials is allowed at home.

Infusion of clover and hawthorn

For the prevention of diseases of the cardiovascular system, as well as for the complex treatment of such diseases, a universal collection is recommended, where the main components are the inflorescences of meadow clover and hawthorn berries.

To prepare such herb collection, the following types of medicinal plants should be joined in equal parts:

- pre-milled willow bark;

- inflorescence of red clover;

- dried or fresh hawthorn berries;

- ziziphora;

- cranberry leaves;

- leaves of ginkgo biloba.

A couple of large tablespoons of the prepared mixture should be filled with half a liter of pre-heated water, and boiled for ten minutes. Use this remedy for half a glass twice a day.

Infusion of lemon balm and yarrow

Effective herbal collection for the cardiovascular system, which includes yarrow and lemon balm, improves the processes of metabolism and circulation, strengthens the vascular walls, and also increases their elasticity several times.

In order to prepare such remedy, it is necessary to prepare a mixture comprising the following kinds of medicinal plants: 
- 2 tbsp. chopped anise seeds;

- 1 tbsp. dried lemon grass;

- 1 tbsp. preliminarily ground valerian roots;

- 1 tbsp. umbrellas of the yarrow.

The resulting mixture in the amount of a dessert spoon should be steamed with a glass of boiling water, then wrap the container with the received infusion with a warm towel and let stand for several hours. Divide the finished medicine into two equal parts, then drink in two meals during the day.

\section{Infusion of motherwort and hawthorn}

Effective treatment of the circulatory system with herbs can be done by taking a collection of hawthorn and motherwort. This variant of the drug mix helps to strengthen and improve the functioning of the heart muscle, cleans the vessels of cholesterol, increases the elasticity of tissues and has a calming effect [5, p. 635].

For its preparation it is necessary to mix:

- one and a half tablespoons of pre-crushed rhizomes of the motherwort;

- 1 tbsp. grass of cudweed;

- a teaspoon of pre-peeled hawthorn berries;

- a teaspoon dried sage grass.

The therapeutic mixture in the amount of just one teaspoon should be brewed with $250 \mathrm{ml}$ of steep boiling water, then let it stand for at least two hours. Depending on the existing diseases, drink such a drug should in the amount of one spoon to half a glass. For the prevention of ailments it is recommended to use $1 \mathrm{tbsp}$. of the prepared drink.

Infusion of mint and valerian

The next version of the herbal collection has a mild sedative effect, promotes the stimulation of metabolic processes and improves blood flow.

In order to prepare such a decoction, the following medicinal herbs should be prepared:

- two parts of the three-sheeted watch;

- two parts of dried leaves of peppermint;

- three parts of the grass of Angelica;

- three parts of the previously crushed rhizome of valerian.

To prepare a healing mixture, you should brew a small handful of herbal mixture of $500 \mathrm{ml}$ of boiling water, and then boil the resulting infusion for 
a minimum of half an hour. The finished product should be consumed in the amount of one third of the glass at least three times a day.

Regardless of which herbal preparations are used for the treatment and prevention of diseases, you should always consult with your doctor before using them. Otherwise, there is a risk of side effects and a significant deterioration in the patient's condition.

\section{Phytotherapy for hypertension}

Hypertensive disease is a very common disease now [8, p. 17-19]. Experts note that the disease is getting younger. This disease is characterized by an increase in blood pressure, as well as a violation of the kidneys, heart, nervous system. Deeper organ changes are observed in the marked stages.

These factors contribute to the development of hypertension:

- heredity,

- functional disorders of the nervous and endocrine systems,

- malnutrition and excess weight,

- bad habits (smoking and drinking alcohol),

- decreased motor activity,

- atherosclerosis in old age,

- bad ecology,

- kidney disease.

Hypertensive disease develops due to the following reasons:

- acute and chronic psychoemotional stresses;

- permanent mental overstrain,

- brain injury and its hypoxia (oxygen starvation),

- age-related hormonal changes (climacteric period),

- salt abuse.

Hypertension can be accompanied by the following symptoms:

- pain and discomfort in the heart,

- headaches, dizziness, hearing loss, noise in the head,

- decreased visual acuity,

- flies, spots, circles before the eyes,

- shortness of breath.

Arterial pressure in hypertensive disease goes beyond the boundary of $140 / 90 \mathrm{~mm} \mathrm{Hg}$.Art. At the beginning of the disease, the pulse is normal, at later stages, its increase and arrhythmia are observed. 
It is important to note that the disease may not manifest itself at an early stage and can be detected accidentally during routine clinical examination.

It is necessary to establish the cause of the disease to treat of hypertension, including medicinal plants.

\section{Plants used for hypertension}

Plants that have a calming, spasmolytic and diuretic effect are usually included in the collection of medicinal plants [4, p. 288]. During the treatment, infusions and broths should be taken for at least 21 days with a 7-day break. The course of treatment lasts at least 3 months.

A soothing effect is possessed by:

- St. John's Wort,

- Motherwort five-lobed,

- Peppermint,

- Valerian officinalis,

- Peony evading,

- Melissa officinalis, etc.

Spasms are removed by:

- Seeds and grass of dill,

- Seeds and fennel grass,

- Chamomile inflorescence,

- Seeds and grass anise ordinary,

- Cleavage grass (papaverin-like action, used in small doses because of toxicity).

Diuretic action have:

- Cowberry ordinary,

- Kidney tea (staminate orthosiphon),

- Bearberry (bear's eye),

- Horsetail,

- Juniper fruit,

- Sporish (mountain bird bird),

- Corn silk,

- Astragalus woollyflower, etc.

In addition, the fees include plants that reduce cholesterol, prothrombin and have antioxidant effects [1, p. 403].

Based on the study of the use of medicinal plants for diseases of the cardiovascular system in Ukraine [9, p. 38-42], we proposed the compositions of some charges for the treatment of cardiovascular diseases. 
The fees № 1

- Mistletoe white, grass - 2 tablespoons,

- Astragalus woollyflower, grass - 1 tablespoon,

- Melissa officinalis, herb - 1 tablespoon,

- Cottonweed, grass - 2 tablespoons.

1 tablespoon mixture pour 1 liter of boiling water, insist in a thermos for 8 hours, drink 30 minutes before eating in 4 divided doses.

Mistletoe and Cottonweed reduce pressure, astragalus relieves swelling, restores kidney function, balm has antispasmodic and sedative (calming) effect.

\section{The fees № 2}

- Valerian officinalis, rhizomes with roots -1 tablespoon,

- Motherwort five-lobed, grass - 1 tablespoon,

- Peppermint leaves - 1 tablespoon,

- Melissa officinalis, herb - 1 tablespoon,

- Hawthorn blood-red fruits - 1 tablespoon,

- St. John's wort treetop - 1 tablespoon,

- Tavolga, grass - 1 tablespoon,

- Donnik yellow, grass -2 teaspoons.

1 tablespoon mixture pour 1 liter of boiling water, insist in a thermos for 8 hours, drink 30 minutes before eating in 4 divided doses.

Valerian, Motherwort, Mint, Lemon balm, St. John's wort have a calming effect. Motherwort not only calms the nervous system, but also reduces pressure, mint and balm are good antispasmodics.

Hawthorn stimulates the function of the heart. Tavolga lowers cholesterol (helps reduce the production of low-density cholesterol), has antioxidant and immunomodulatory effects, reduces prothrombin. Donnik is thinning the blood.

In hypertension, accompanied by insomnia, the following elixir has proved to be well:

- Motherwort of grass $50 \mathrm{~g}$,

- Peony dodging root (buy at the pharmacy) $50 \mathrm{~g}$,

- Valerian rootstocks with roots of $50 \mathrm{~g}$,

- St. John's wort $20 \mathrm{~g}$,

- Chamomile inflorescences $50 \mathrm{~g}$,

- Peppermint leaves $50 \mathrm{~g}$,

- Hawthorn fruits $10 \mathrm{~g}$. 
Pour 0,5 liters of vodka and leave for 7 days, shaking daily. On the 8 th day, it is necessary to strain, add slightly warmed honey as much by volume as the alcohol tincture turns out. Mix the whisk until it is uniform. Keep refrigerated. Take 1 teaspoonful in the evening 2 hours after eating.

Taking plant remedies for hypertension, it is important to remember that the first cause of hypertension is stress. The desire to achieve high social goals and standards of social life leads to chronic stress. The desire to surround yourself with all the benefits of modernity makes a person work harder for wear and tear. As a result, our soul and body suffer.

\section{Conclusions}

Some plants, used to treat cardiovascular diseases, have been discussed above. The list of plants, that were given, reflects the main approaches to phytotherapy of diseases of the cardiovascular system: this is the use of cardiac glycosides - the first highly effective drugs for the treatment of heart failure, P-active compounds, strengthening blood vessels and regulating metabolism in the body, various alkaloids, stimulating the activity of the body, which is important, for example, in hypotension. A number of medicinal plants are representatives of the ruderal flora (Motherwort). It causes widespread use of plants in folk medicine. Individual plants are introduced into the culture to produce medicinal products based on them (Valerian, Digitalis, Periwinkle, Astragalus). We learned that plants are widely used in medicine. A significant part of modern pharmaceuticals, used for the treatment of cardiovascular diseases, is the continuation of those approaches that were started by the use of herbal preparations.

\section{References:}

1. Barnaulov O. D. (2010) Fitoterapiya bol'nykh serdechno-sosudistymi zabolevaniyami [Phytotherapy of patients with cardiovascular diseases]. Petersburg. (in Russian)

2. Korsun V. F., Korsun E. V., Malyshko M. A. (2012) Istoriya fitoterapii v Belarusi [History of phytotherapy in Belarus]. Moscow - Minsk. (in Russian)

3. Korsun V. F., Roizman S. A., Chuyko T.V. (2003) Fitoterapiya serdechno-sosudistykh zabolevaniy [Phytotherapy of cardiovascular diseases]. Minsk. (in Russian)

4. Kryvtsk A. A., Kuntcevich L. P. (2001) Rastitel'nyy svet: tematich. slov. [Vegetable world: thematic vocabulary]. Minsk. (in Russian)

5. Ogrenich N. A. (2014) Metodologiya fitoterapii [Methodology of phytotherapy]. (in Russian) 
6. Sakhanda I. V., Nehoda T. S., Syatynya M. L. (2015) Ekspertna ocinka terapevtychnoji efektyvnosti likarsjkykh zasobiv roslynnogho pokhodzhennja, shho vykorystovujutjsja pry sercevo-sudynnykh zakhvorjuvannjakh [Expert estimation of therapeutic effectiveness of medicinal herbs used in cardiovascular diseases]. International scientific-practical conference "Modern medicine: topical issues" (Odessa, November 20-21, 2015), pp. 12-13.

7. Syatynya M. L., Nehoda T. S., Sakhanda I. V. (2015) Rol' rastitel'nykh lekarstvennykh sredstv v profilaktike i lechenii serdechno-sosudistykh zabolevaniy [The role of herbal medicines in the prevention and treatment of cardiovascular diseases]. XI International Scientific and Practical Conference "Education and Science of the XXI Century - 2015" (Sofia, Bulgaria, 15-22.10.2015), pp. 12-14.

8. Syatynya M. L., Nehoda T. S., Sakhanda I. V. (2015) Struktura i dinamika razvitiya serdechno-sosudistoy zabolevaemosti naseleniya [Structure and dynamics of the development of cardiovascular morbidity in the population]. XI International Scientific and Practical Conference "Science and Innovations-2015" (Przemysl, Poland, 07-15.10.2015), pp. 17-19.

9. Syatynya M. L., Nehoda T. S., Sakhanda I. V. (2015) The use of medicinal plants the treatment of cardiovascular diseases. Nauka i studia, Przemysl, pp. $38-42$. 